\title{
SUOMEN MAATALOUSTIETEELLISEN SEURAN \\ SÄÄNNÖT
}

$1 \S$.

Seuran nimi on Suomen Maataloustieteellinen Seura - Lantbruksvetenskapliga Samfundet i Finland; sen kotipaikka on Helsingin kaupunki.

Seuran tarkoituksena on edistää ja kannattaa kotimaista tutkimustyötä maatalouden eri aloilla.

$2 \S$.

Tarkoitustaan koettaa seura toteuttaa etupäässä

toimittamalla julkaisuja;

järjestämällä kokouksia esitelmineen, tiedonantoineen ja keskusteluineen;

toimeenpanemalla tiedusteluja (enquête);

avustamalla tutkimuksia ja kokeita sekä jakamalla stipendejä ja

liittymällä yhteistoimintaan samanlaisten koti- sekä ulkomaisten seurojen kanssa.

$3 \S$.

Seura kutsuu

vakinaiseksi jäseneksi kotimaisen henkilön, joka voi edistää seuran tarkoitusta;

kirjeenvaihtajajäseneksi ulkomaisen tutkijan, jonka toiminta on edistänyt seuran tarkoitusta;

kunniajäseneksi koti- tai ulkomaisen henkilön, jota seura erikoisesti tahtoo kunnioittaa; sekä

kannattajajäseneksi seuran tarkoitusperää harrastavan henkilön, joka sitoutuu kerta kaikkiaan maksamaan vähintäin 2.500 markkaa tai viiden vuoden aikana vuosittain vähintäin 500 markkaa.

Vuosikokouksessa päätetään, kannetaanko kuluvalta kalenterivuodelta vakinaisilta jäseniltä jäsenmaksua sekä tämän maksun suuruudesta. Kirjeenvaihtajaja kunniajäseniltä ei maksua kanneta. 
$4 \S$.

Uuden jäsenen valitsemisesta tekee kaksi vakinaista jäsentä puheenjohtajalle kirjallisen ehdotuksen varsinaisessa kokouksessa. Seuraavassa kokouksessa toimitetaan vaali suljetuin lipuin äänestämällä. Jos ehdotusta $2 / 3$ äänestäneistä on kannattanut, annetaan valitulle kirjallinen kutsumus. Kunnia- ja kirjeenvaihtajajäsen valitaan vuosikokouksessa samalla tavalla.

Jäsen, joka ei noudata seuran sääntöjä tai vastustaa sen pyrintöjä, voidaan eroittaa seurasta.

Kysymys jäsenen mahdollisesta eroittamisesta seurasta käsitellään samassa järjestyksessä kuin jäsenen valitseminen.

$5 \S$.

Seuran vakinaiset jäsenet valitsevat ensimmäiseksi toimintavuodeksi puheenjohtajan ja varapuheenjohtajan sekä sittemmin vuosittain varapuheenjohtajan, joka tulee seuraavana vuonna puheenjohtajaksi. Seuran sihteeri, rahastonhoitaja sekä kirjastonhoitaja valitaan kolmeksi vuodeksi ja voidaan heidät uudestaan valita. Ensi kerralla valitaan kaksi tilintarkastajaa, toinen kahdeksi, toinen yhdeksi vuodeksi, sittemmin kunakin vuonna yksi tilintarkastaja kahdeksi vuodeksi. Samalla tavalla toimitetaan kahden varatilintarkastajan vaali.

$6 \S$.

Seuran toimihenkilöt valitaan suljetuin lipuin helmikuussa pidettävässä vuosikokouksessa. Toimihenkilöiden vaihdos tapahtuu heti vuosikokouksen jälkeen.

$7 \S$.

Seuran vakinaiset kokoukset pidetään joka tai joka toinen kuukausi syyskuun ensimmäisen ja kesäkuun ensimmäisen päivän välisenä aikana. Ylimääräisiä kokouksia pidetään tarpeen mukaan.

Seuran kokouksissa on äänioikeus ainoastaan läsnäolevilla vakinaisilla jäsenillä.

Vuosikokouksessa, joka pidetään helmikuussa, toimitetaan toimihenkilöiden vaalit ja esitetään johtokunnan kertomus edellisen vuoden toiminnasta sekä tilintarkastajien lausunto, jonka jälkeen käsitellään kysymys vastuuvapauden myöntämisestä johtokunnalle.

$8 \S$.

Seuran kokoukset kutsutaan kokoon, jäsenille postin välityksellä toimitettavilla kirjeillä taikka kuulutuksilla ainakin yhdessä suomen- ja yhdessä ruotsinkielisessä pääkaupunkilaisessa päivälehdessä. Kokouskutsut ovat toimitettavat postiin tai kuulutettavat vähintäin kaksi päivää ennen kokouspäivää.

Samalla tavalla toimitetaan muut tiedonannot jäsenille.

$9 \S$.

Tarvittaessa voi seura jakaantua osastoihin. 
$10 \S$.

Seuran kokousten pöytäkirjoihin merkitään asiat sillä kotimaisella kielellä, jolla ne on vireille pantu. Kuitenkin on jokaisella jäsenellä oikeus saada lausuntonsa pöytäkirjaan haluamallaan kielellä. Sellaisiin seuran julkaisuihin, jotka toimitetaan jommallakummalla kotimaisella kielellä, liitetään saksan-, ranskan- tai englanninkielinen selonteko niiden sisällyksestä.

$11 \S$.

Seuran juoksevia asioita hoitaa johtokunta, jonka jäseninä ovat seuran puheenjohtaja, varapuheenjohtaja, sihteeri ja rahastonhoitaja. Johtokunta on päätösvaltainen, kun kolme jäsentä on saapuvilla.

Seuran nimen merkitsevät puheenjohtaja ja sihteeri yhdessä.

$12 \S$.

Ehdotus näiden sääntöjen muuttamisesta tai seuran toiminnan lopettamisesta tehdään varsinaisessa kokouksessa, ja on ehdotus hyväksytty, jos 3/4 läsnäolevista vakinaisista jäsenistä on sitä kannattanut kahdessa varsinaisessa kokouksessa, joista jälkimäisen tulee olla vuosikokous.

$13 \S$.

Siinä tapauksessa, että seura lopettaa toimintansa, on sen omaisuus varsinaisen kokouksen päätöksen mukaisesti luovutettava jollekin kotimaiselle seuralle tai laitokselle samaan tarkoitukseen käytettäväksi.

Yhdistyksen rekisterinumero 7969. Merkitty yhdistysrekisteriin siv. 361 Y.R. 29.

Sosialiministeriö on hyväksynyt tämän yhdistyksen merkittäväksi yhdistysrekisteriin ja on yhdistyksen nimeen liitetty r.y. r.f.

Helsingissä, Sosialiministeriössä 5 p:nä maaliskuuta 1923.

$$
\begin{gathered}
\text { J. A. Eklund. } \\
\text { mtty. }
\end{gathered}
$$

Martta Juntunen.

(Valtioneuvoston sinetti.) 